\title{
LINKAGE AND HAPLOTYPE ANALYSIS OF FAMILIAL EARLY-ONSET ALZHEIMER DISEASE IN JAPANESE POPULATION
}

\author{
Kouzin Kamino, ${ }^{1, *}$ Keiko Nagano, ${ }^{1}$ Tomohiro Katsuya, ${ }^{1}$ \\ Yumiko Nishiwaki, ${ }^{1}$ Masatoshi Takeda, ${ }^{2}$ Hirotaka Tanabe, ${ }^{2}$ \\ Tsuyoshi Nishimura, ${ }^{2}$ Kunio II, ${ }^{3}$ Kenzo Fujimoto, ${ }^{4}$ \\ Ryotaro Tsujimura, ${ }^{5}$ Yasubiro Nonomura, ${ }^{6}$ Hiroshi Yoneda, ${ }^{6}$ \\ Toshiaki SaKaI ${ }^{6}$ Teruo NaKaJima, ${ }^{7}$ Masaki Imagawa, ${ }^{8}$ \\ George M. Martin, ${ }^{9}$ Thomas D. Bird, ${ }^{10}$ Gerard S. Schellenberg, ${ }^{11}$ \\ Tetsuro Miki, ${ }^{1}$ and Toshio OGIHARA ${ }^{1}$
}

\footnotetext{
${ }^{1}$ Department of Geriatric Medicine and ${ }^{2}$ Department of Psychiatry, Osaka University Medical School, 2-2 Yamadaoka, Suita 565, Japan ${ }^{3}$ First Department of Pathology and ${ }^{4}$ Department of Neuropsychiatry, School of Medicine, University of Tokushima, 3-8-15 Kuramoto-cho, Tokushima 770, Japan

${ }^{5}$ Department of Psychiatry, Mie University Medical School, 2-174 Edobashi, Tsu 514, Japan

${ }^{6}$ Department of Neuropsychiatry, Osaka Medical College, 2-7 Daigaku-cho, Takatsuki 569, Japan

${ }^{7}$ Department of Psychiatry, Kyoto Prefectural Medical College, Hirokoji, Kawara-machi, Kamigyo-ku, Kyoto 602, Japan

${ }^{8}$ Department of Neuropsychiatry and Neurology, Hyogo Prefectural Amagasaki Hospital, Amagasaki 660, Japan

${ }^{9}$ Department of Pathology, University of Washington, Seattle, Washington 98195, USA

${ }^{10}$ Division of Neurology and "Geriatric Research, Education, and Clinical Center (182B),

Veterans Affairs Medical Center, Seattle, Washington 98108, USA
}

Summary Linkage and haplotype analysis of eleven early-onset Alzheimer disease (AD) families was performed in relation to D21S210 and microsatellite DNA polymorphisms localized on chromosome 14q24.3. Linkage analysis of eight informative families out of eleven early-onset AD families disclosed the highest LOD score of $3.45(\theta=0.00)$ at D14S77, while the locus of $\beta / A 4$ amyloid protein precursor gene was formally excluded within $10 \mathrm{cM}$ from D21S210, given the evidence of recombinations in five families. Transmission disequilibrium study between the patients and controls without dementia indicated significant differences at D14S43 $(p=0.0001)$ and D14S71 $(p=0.02)$. Association study be-

Received April 17, 1995; Revised version accepted June 14, 1995.

* To whom correspondence should be addressed. 
tween genotypes linked or related to onset of $A D$ and those of control also revealed a significant difference at D $14 S 43(\mathrm{p}<0.05)$, suggesting the existence of linkage disequilibrium. Moreover, the haplotypes at D14S43 linked with the onset of $\mathrm{AD}$ indicated a significant relationship with the mean age at onset. These results support that the major locus of earlyonset familial AD is located on $14 q 24.3$, and its close linkage to D14S43 and the existence of allelic heterogeneity were suggested.

Key Words Alzheimer disease, genetics, B/A4 amyloid protein precursor, chromosome 14

\section{INTRODUCTION}

The familial form of Alzheimer disease (AD) is an autosomal dominant disorder of the brain characterized by progressive dementia that occurs in middle or late life. The pathologic characteristics are the presence of neuritic plaques and neurofibrillary tangles, which are predominantly found in the cerebral cortex and the hypocampus. Research on familial Alzheimer disease (FAD) has been focused on elucidating the genetic factors for the onset of AD, and linkage analyses have been performed to identify the loci for early-onset FAD, defined by the age at onset of not more than 65 years old. Several early-onset AD families were shown to be linked with mutations of the $\beta / A 4$ amyloid protein precursor (APP) gene (Goate et al., 1991; Murrel et al., 1991; Chartier-Harlin et al., 1991; Mullan et al., 1992a). The mutation producing the ${ }^{712} \mathrm{Val} \rightarrow$ Ile substitution at codon 717 of the APP gene had also been identified in Japanese early-onset AD families (Naruse et al., 1991; Yoshioka et al., 1991; Yoshizawa et al., 1993). Large scale mutational analyses and linkage analyses, however, indicated that the APP gene is not a major causative gene of early-onset FAD (Kamino et al., 1992; Tanzi et al., 1992; Yoshizawa et al., 1993; Fujigasaki et al., 1994). Microsatellite polymorphisms mapped to 14q24.3 were shown to be linked in several early-onset AD families (Schellenberg et al, 1992), and subsequent reports strongly suggested that a major locus for early-onset FAD is located on 14q24.3 (St George-Hyslop et al., 1992; Van Broeckhoven et al., 1992; Mullan et al., 1992b). But the absence of linkage on 14q24.3 in VolgaGerman families (Schellenberg et al., 1992) and Swedish families (Lannfelt et al., 1993) indicated that early-onset FAD with relatively later age at onset could be caused by other genes at unknown loci.

Linkage analysis is a relevant strategy to define a disease locus, and relies upon recombination events in families with the disease. In the case of an adult-onset disease, linkage analysis is based on an assumption of age-dependent penetrance of the disease phenotype (Pericak-Vance et al., 1979). Linkage disequilibrium, on the other hand, allows fine localization of gene loci, and linkage disequilibrium mapping has also been utilized for positional cloning (Harley et al., 1991; Haestbacka et al., 1994). Transmission disequilibrium study can be used to support mapping studies (Takiyama et al., 1993). Linkage disequilibrium is based on the 
restricted number of origins of disease mutations, called the founder effect. However, linkage disequilibrium studies are confounded by population admixture. In this respect, a single homogeneous population can be expected to yield more reliable information. Here, we investigated the genotypes of eleven Japanese early-onset FAD kindred using microsatellite polymorphisms on $14 \mathrm{q} 24.3$ and performed linkage and haplotype analysis. Our findings supported that a major locus of early-onset FAD is located on $14 \mathrm{q} 24.3$. Our results also suggested that the locus is localized close to D14S43, and that allelic heterogeneity exists in early-onset FAD.

\section{MATERIALS AND METHODS}

Families and controls. Patients from eleven families with early-onset FAD were diagnosed according to the criteria of NINCDS-ADRDA (McKhann et al., 1984), and blood samples were obtained with informed consent from 63 individuals. Autopsy findings confirmed the diagnosis in four families, TK-1 (IV-5, -10, -11, and -15), ME (II-4), KF (II-2 and -3), and AM (II-1) (Schellenberg et al., 1991). Autopsy materials were obtained from IV-5, IV-10, and IV-15 of TK-1, and II-2 and II-3 of KF, and DNAs of these cases were extracted from paraffin blocks. In $\mathrm{KT}$, AC-2, and HG-5, a blood sample was obtained from one patient in each family. The mean age at onset in all families was $43.3 \pm 4.0$ years old, and the pedigrees are shown in Fig. 1 (Nagano et al., 1995). DNAs of 50 independent controls without dementia, including 10 normal spouses in TK-1, ME, and OS-3, were utilized to determine allele frequencies in the Japanese population.

Analysis with microsatellite markers. D21S210 (Warren et al., 1993) was used to assess linkage with the APP locus. DI4S53 (Wang and Wever, 1992), D14S43 (Sharma et al., 1991), D14S71, D14S76, and D14S77 (Weissenbach et al., 1992) were genotyped for the region on 14q24.3. To obtain better resolution for genotyping D14S77, the primer of 5'-CACTGTGCCCAGCCTGAGAATT-3' was used as the CA strand primer. Linkage analyses of AM family using D21S210, D14S43, and D14S53 have been reported previously (Kamino et al., 1992; Schellenberg et al., 1992), but we determined the genotypes again to measure their allele sizes. First, 100 pmol of $5^{\prime}$-primer was endlabeled with $5.0 \mu 1$ of $\left[\gamma^{-32} \mathrm{P}\right]$-ATP $(5,000$ $\mathrm{Ci} / \mathrm{mmol}$ ) using $10 \mathrm{U}$ of $\mathrm{T} 4$ polynucleotide kinase in a total volume of $20 \mu \mathrm{l}$ and the mixture was diluted to 1 pmol $5^{\prime}$-primer/ul with $\mathrm{H}_{2} \mathrm{O}$. The PCR reaction was carried out in a total volume of $10 \mu \mathrm{l}$ and was composed of $100 \mathrm{ng}$ DNA, 200 $\mu \mathrm{M}$ of each dNTP, $0.4 \mu \mathrm{M}$ 5'-primer, $0.1 \mu \mathrm{M}{ }^{32} \mathrm{P}$-endlabeled 5'-primer, $0.5 \mu \mathrm{M} 3^{\prime}$ primer, $1.5 \mathrm{mM} \mathrm{MgCl}$ (2.0 mM for D14S53 and D14S76, $1.0 \mathrm{~mm}$ for D14S77), 50 $\mathrm{mM} \mathrm{KCl}, 10 \mathrm{~mm}$ Tris- $\mathrm{HCl}(\mathrm{pH} 8.4$ ), $0.001 \%$ gelatin and $0.25 \mathrm{U} / 10 \mu \mathrm{l}$ of Taq DNA polymerase. The PCR thermocycling was as follows: $94^{\circ} \mathrm{C}$ for $45 \mathrm{sec}, 55^{\circ} \mathrm{C}$ for $30 \mathrm{sec}, 72^{\circ} \mathrm{C}$ for $45 \mathrm{sec}$ with an additional $1 \mathrm{sec}$ in each cycle (35 cycles) for D14S71 and D14S76; $94^{\circ} \mathrm{C}$ for $45 \mathrm{sec}, 60^{\circ} \mathrm{C}$ for $30 \mathrm{sec}, 72^{\circ} \mathrm{C}$ for $45 \mathrm{sec}$ with an additional $1 \mathrm{sec}$ in each cycle $(35 \mathrm{cycles})$ for $\mathrm{D} 14 \mathrm{~S} 77 ; 96^{\circ} \mathrm{C}$ for $1 \mathrm{~min}, 51^{\circ} \mathrm{C}$ for $30 \mathrm{sec}, 72^{\circ} \mathrm{C}$ 


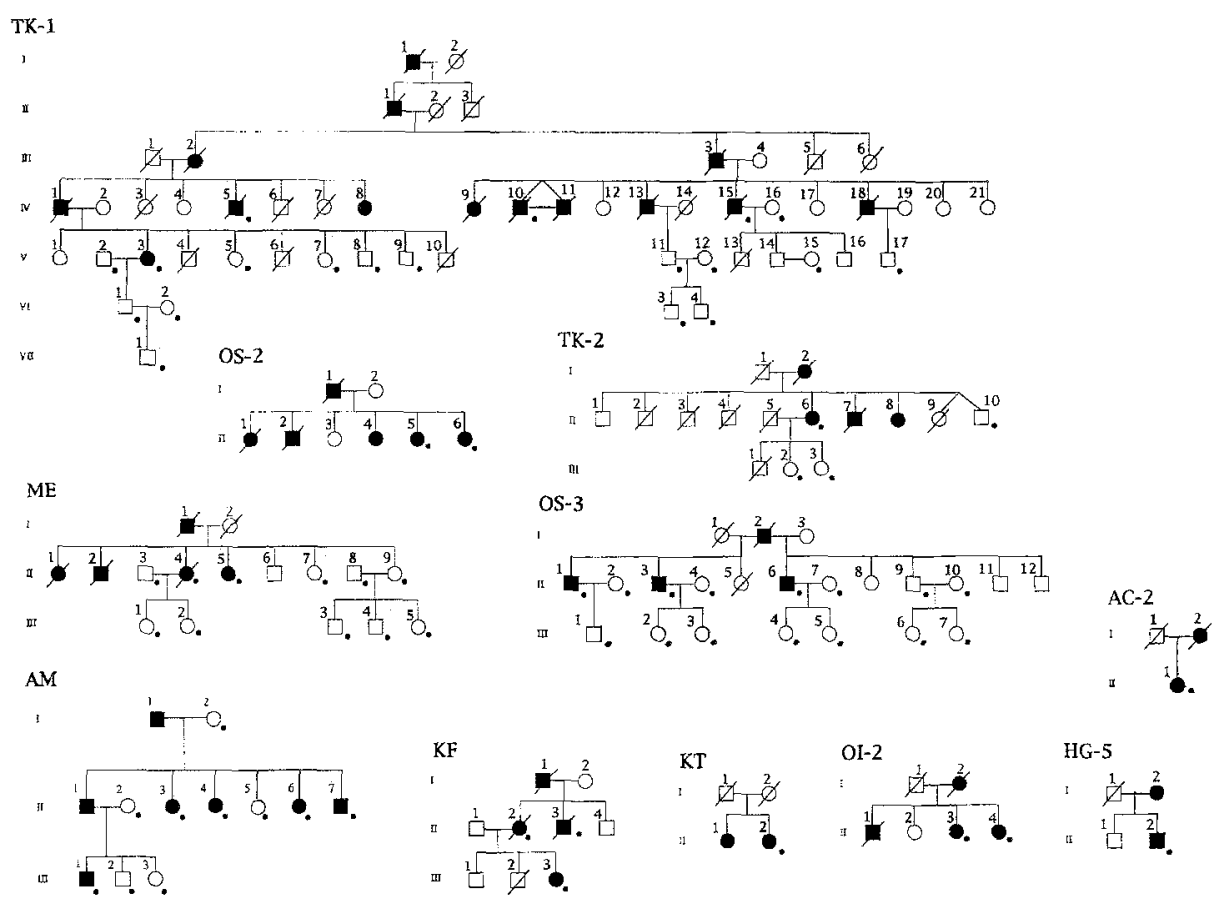

Fig. 1. Pedigrees of 11 Japanese early-onset FAD families. Smail black circles represent persons whose DNA was analyzed. $\square$, males; $\bigcirc$, females; $\boldsymbol{\square}, \mathbf{0}$, affected; $\square, O$, unaffected.

for $90 \mathrm{sec}\left(30\right.$ cycles) for $\mathrm{D} 21 \mathrm{~S} 210 ; 96^{\circ} \mathrm{C}$ for $1 \mathrm{~min}, 55^{\circ} \mathrm{C}$ for $30 \mathrm{sec}, 72^{\circ} \mathrm{C}$ for $1 \mathrm{~min}$ with an additional $1 \mathrm{sec}$ in each cycle ( 35 cycles) for D14D53 and D14S43.

The PCR products were mixed with an equal volume of formamide loading

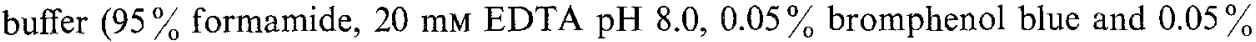
xylene cyanol), denatured at $95^{\circ} \mathrm{C}$ for $3 \mathrm{~min}$ and applied to a $6 \%$ denaturing polyacrylamide DNA sequencing gel containing $46 \%$ urea, 30\% formamide and $2 \times$ TBE $(1 \times$ TBE: $0.1 \mathrm{~m}$ boric acid, $2 \mathrm{~mm}$ EDTA and $0.09 \mathrm{~m}$ Tris- $\mathrm{HCl} \mathrm{pH} \mathrm{8.3).} \mathrm{Gels}$ were fixed, dried and exposed to Fuji Rx film at $-80^{\circ} \mathrm{C}$ for several days. Allele sizes for D14S76, D14S71, and D14S77 were determined by comparison with those of the CEPH reference sample 134,702, and those of D21S210, D14S53, and 14S43 by comparison with M13 DNA sequencing ladder. DNA typing was performed without prior knowledge of the pedigree structure. In each case, the samples for the reference allele were run concurrently as a size control. Mendelian segregation of alleles was observed in all cases. Genotyping using DNA obtained from paraffin blocks was confirmed by identical results of at least two independent samples.

Statistical analysis. Linkage analyses were performed for eight Japanese early-onset $\mathrm{AD}$ families. Two-point lod scores were calculated using MLINK and LODSCORE of the LINKAGE package, version 5.1. Early-onset FAD 
was considered as an autosomal dominant disease with a frequency of 0.001 , and equal female to male recombination rates were applied. Thirteen penetrance classes were used based on the cumulative risk curve, which was obtained from the mean age at onset of the patients in each family (Ott, 1991).

Transmission disequilibrium between the early-onset FAD locus and marker loci was assessed by $\chi^{2}$ statistics according to the method previously defined for multiallelic loci (Weir and Cockerham, 1978). Association due to linkage disequilibrium was evaluated by comparison of allele frequencies of the linked alleles in the patients and the controls basically as described (Yu et al., 1994). Namely, when one common haplotype or allele was observed among the patients, only a single allele was counted. In the case of recombination, both alleles were counted. When the linked allele could not be determined, two alleles of a patient were included. The allele that was overrepresented among early-onset FAD chromosomes was defined as one allele, and all of the other alleles were combined to form a second allele. The usual $\chi 2$ test for $2 \times 2$ tables was then applied to determine significance. A p-value of less than 0.05 was considered to indicate significance.

The early-onset FAD families were divided into three groups based on the D14S43 allele co-segregating with the disease, and the differences of age at onset were evaluated by analysis of variance (ANOVA). Then, differences of the mean age at onset between the groups were further evaluated by Fisher's PLSD test.

\section{RESULTS}

\section{Linkage analysis}

To evaluate the linkage between the onset of FAD and the APP gene, Japanese early-onset FAD families were genotyped at D21S210 (Table 1), which is localized within $1 \mathrm{cM}$ from the APP gene (Warren et al., 1993). Recombinations between the onset and D21S210 were found in five families, and overall linkage was formally excluded within $10 \mathrm{cM}$ from D21S210 (Table 2). Moreover, direct sequencing of exon 17 of the APP gene did not show any mutations in TK-1, TK-2, ME, KT, and OS-2 (Yoshioka et al., 1991). No mutations in exon 16 and 17 of the APP gene were identified in the eleven families by mutational analysis using mismatched PCR-RFLP (submitted data). These results indicate that the APP gene is not a causative gene.

Then we investigated the linkage of FAD to chromosome 14q24.3 (Table 1). Linkage analysis between D14S77 and early-onset FAD indicated positive linkage, and no recombinations were found $\left(Z_{\max }=3.45\right.$ at $\theta=0.00 ; 1.50$ for AM family and 1.95 for the others). No recombinations between D14S43 and AD phenotype were also observed $\left(Z_{\max }=0.95\right.$ at $\left.\theta=0.00\right)$. Recombination events were observed in D14S53 and D14S76 for TK-1, and in D14S71 for KF. All of these recombinations were detected in the cases in which DNAs were extracted from paraffin blocks. The overall two-point linkage analysis is summarized in Table 2. 
Table 1. Two-point linkage analysis of eight Japanese early-onset FAD families.

\begin{tabular}{|c|c|c|c|c|c|c|c|c|}
\hline DNA marker & familv $>\theta$ & 0.00 & 0.01 & 0.05 & 0.10 & 0.20 & 0.30 & 0.40 \\
\hline \multirow[t]{8}{*}{ D21S210 } & TK-1 & $-\inf$ & -2.50 & -1.19 & -0.68 & -0.28 & -0.12 & 0.05 \\
\hline & $T K-2$ & 0.05 & 0.05 & 0.04 & 0.03 & 0.02 & 0.01 & 0.00 \\
\hline & $0 s-2$ & -0.14 & -0.13 & -0.11 & -0.08 & -0.05 & -0.02 & -0.00 \\
\hline & $0 S-3$ & -2.40 & -1.36 & -0.72 & -0.44 & -0.19 & -0.08 & -0.02 \\
\hline & $M E$ & -0.59 & -0.59 & -0.55 & -0.45 & -0.25 & -0.11 & -0.03 \\
\hline & $\mathrm{KF}$ & -2.70 & -1.29 & -0.63 & -0.37 & -0.15 & -0.05 & -0.01 \\
\hline & $01-2$ & -2.70 & -1.38 & -0.72 & -0.44 & -0.19 & -0.08 & -0.02 \\
\hline & AM & -3.20 & -2.18 & -0.91 & -0.42 & -0.05 & 0.06 & 0.06 \\
\hline \multirow[t]{8}{*}{014553} & $T K-1$ & -3.11 & -1.73 & -0.90 & -0.52 & -0.20 & -0.07 & -0.01 \\
\hline & $T K-2$ & 0.12 & 0.11 & 0.10 & 0.08 & 0.05 & 0.02 & 0.01 \\
\hline & $0 S-2$ & 0.10 & 0.09 & 0.08 & 0.06 & 0.04 & 0.02 & 0.00 \\
\hline & $0 S-3$ & 0.01 & 0.01 & 0.01 & 0.01 & 0.01 & 0.00 & 0.00 \\
\hline & ME & 0.68 & 0.66 & 0.60 & 0.52 & 0.35 & 0.18 & 0.05 \\
\hline & $K F$ & -0.20 & -0.19 & -0.16 & -0.12 & -0.06 & -0.03 & -0.01 \\
\hline & $01-2$ & -0.20 & -0.19 & -0.16 & -0.12 & -0.06 & -0.03 & -0.01 \\
\hline & AMI & 1.80 & 1.77 & 1.65 & 1.48 & 1.12 & 0.72 & 0.29 \\
\hline \multirow[t]{8}{*}{ D1 4543} & TK-I & -0.20 & -0.18 & -0.11 & -0.06 & -0.01 & -0.00 & -0.00 \\
\hline & TK-2 & 0.26 & 0.25 & 0.22 & 0.18 & 0.11 & 0.05 & 0.01 \\
\hline & $0 S-2$ & 0.20 & 0.19 & 0.17 & 0.14 & 0.08 & 0.04 & 0.01 \\
\hline & $0 S-3$ & 0.21 & 0.21 & 0.18 & 0.15 & 0.09 & 0.04 & 0.01 \\
\hline & ME & 0.61 & 0.59 & 0.52 & 0.44 & 0.27 & 0.13 & 0.04 \\
\hline & $K F$ & 0.00 & 0.00 & 0.00 & 0.00 & 0.00 & 0.00 & 0.00 \\
\hline & $01-2$ & -0.11 & -0.10 & -0.08 & -0.07 & -0.04 & -0.02 & -0.00 \\
\hline & $A M$ & -0.03 & -0.02 & 0.01 & 0.03 & 0.03 & 0.02 & 0.01 \\
\hline \multirow[t]{8}{*}{ D14S77 } & TK-1 & 0.74 & 0.72 & 0.64 & 0.55 & 0.35 & 0.19 & 0.07 \\
\hline & $T K-2$ & 0.09 & 0.08 & 0.07 & 0.06 & 0.03 & 0.02 & 0.00 \\
\hline & $O S-2$ & -0.24 & -0.23 & -0.18 & -0.14 & -0.07 & -0.03 & -0.01 \\
\hline & $0 S-3$ & 0.59 & 0.58 & 0.52 & 0.46 & 0.31 & 0.17 & 0.05 \\
\hline & $M E$ & 0.63 & 0.62 & 0.56 & 0.48 & 0.31 & 0.16 & 0.05 \\
\hline & $K F$ & -0.09 & -0.09 & -0.07 & -0.05 & -0.02 & -0.01 & -0.00 \\
\hline & $01-2$ & 0.23 & 0.23 & 0.20 & 0.16 & 0.10 & 0.05 & 0.01 \\
\hline & AM & 1.50 & 1.47 & 1.36 & 1.22 & 0.91 & 0.56 & 0.20 \\
\hline
\end{tabular}

\section{Haplotype analysis}

To evaluate linkage disequilibrium, transmission disequilibrium between the early-onset FAD locus and marker loci on 14q24.3 was investigated by comparison 
Table 2. Summary of two-point linkage analysis of eight Japanese early-onset.

\begin{tabular}{lcrrrrrrr}
\hline Marker $\backslash \theta$ & 0.00 & 0.01 & 0.05 & 0.10 & 0.20 & 0.30 & 0.40 & \multicolumn{1}{c}{$Z_{\max }(\theta)$} \\
\hline D21S210 & \multicolumn{1}{c}{ inf } & -9.38 & -4.79 & -2.85 & -1.14 & -0.39 & -0.07 & \\
D14S53 & -0.80 & 0.53 & 1.22 & 1.39 & 1.25 & 0.81 & 0.32 & $1.39(0.11)$ \\
D14S76 & - inf & 1.66 & 2.07 & 1.98 & 1.50 & 0.91 & 0.33 & $2.07(0.05)$ \\
D14S43 & 0.95 & 0.94 & 0.91 & 0.81 & 0.53 & 0.26 & 0.08 & $0.95(0.00)$ \\
D14S71 & -1.09 & 0.32 & 0.90 & 0.98 & 0.81 & 0.48 & 0.19 & $0.98(0.10)$ \\
D14S77 & 3.45 & 3.38 & 3.10 & 2.74 & 1.92 & 1.11 & 0.37 & $3.45(0.00)$ \\
\hline
\end{tabular}

Table 3. Transmission disequilibrium study of Japanese early-onset FAD patients with microsatellite polymorphisms on $14 \mathrm{q} 24.3$.

\begin{tabular}{|c|c|c|c|c|c|c|c|c|c|c|c|c|c|c|c|}
\hline \multirow[t]{3}{*}{ Marker } & \multicolumn{3}{|c|}{ D14S53 } & \multicolumn{3}{|c|}{ D14S76 } & \multicolumn{3}{|c|}{ D14S43 } & \multicolumn{3}{|c|}{ D14S71 } & \multicolumn{3}{|c|}{ D14S77 } \\
\hline & \multirow{2}{*}{\multicolumn{2}{|c|}{$\stackrel{(b p)}{\text { Control }}$}} & \multirow[b]{2}{*}{$\mathrm{AD}$} & \multirow{2}{*}{\multicolumn{2}{|c|}{ (bp) }} & & \multirow{2}{*}{\multicolumn{2}{|c|}{ (bp) }} & \multirow[b]{2}{*}{$A D$} & \multirow{2}{*}{\multicolumn{2}{|c|}{ (bp) }} & \multirow{2}{*}{$\mathrm{AD}$} & \multirow{2}{*}{\multicolumn{2}{|c|}{ (bp) }} & \multirow{2}{*}{$\mathrm{AD}$} \\
\hline & & & & & & $\mathrm{AD}$ & & & & & & & & & \\
\hline 1 & 144 & 11 & 4 & 163 & 1 & 0 & 161 & 18 & 4 & 193 & 5 & 3 & 201 & 2 & 0 \\
\hline 2 & 146 & 1 & 0 & 165 & 1 & 0 & 167 & 0 & 4 & 195 & 8 & 7 & 203 & 0 & 2 \\
\hline 3 & 147 & 1 & 0 & 167 & 14 & 10 & 175 & 8 & 0 & 197 & 21 & 2 & 205 & 1 & 1 \\
\hline 4 & 148 & 4 & 0 & 169 & 0 & 1 & 181 & 3 & 0 & 199 & 3 & 0 & 207 & 15 & 10 \\
\hline 5 & 149 & 3 & 0 & 171 & 21 & 14 & 183 & 1 & 3 & 201 & 8 & 3 & 209 & 1 & 0 \\
\hline 6 & 150 & 1 & 0 & 173 & 1 & 1 & 185 & 17 & 2 & 203 & 12 & 2 & 211 & 1 & 0 \\
\hline 7 & 151 & 60 & 34 & 177 & 9 & 2 & 186 & 0 & 1 & 205 & 2 & 5 & 213 & 10 & 2 \\
\hline 8 & 153 & 5 & 2 & 179 & 47 & 20 & 187 & 28 & 25 & 207 & 37 & 18 & 215 & 37 & 13 \\
\hline 9 & 155 & 9 & 9 & 181 & 3 & 2 & 189 & 9 & 6 & 209 & 3 & 0 & 217 & 5 & 4 \\
\hline 10 & 157 & 1 & 1 & 183 & 3 & 0 & 191 & 14 & 1 & 211 & 1 & 2 & 219 & 6 & 1 \\
\hline 11 & 159 & 4 & 0 & & & & 193 & 1 & 0 & & & & 221 & 5 & 1 \\
\hline 12 & & & & & & & [95 & 1 & 0 & & & & 223 & 0 & 2 \\
\hline 13 & & & & & & & & & & & & & 225 & 3 & 2 \\
\hline 14 & & & & & & & & & & & & & 227 & 1 & 0 \\
\hline 15 & & & & & & & & & & & & & 229 & 3 & 0 \\
\hline 16 & & & & & & & & & & & & & 231 & 5 & 0 \\
\hline 17 & & & & & & & & & & & & & 233 & 2 & 3 \\
\hline 18 & & & & & & & & & & & & & 235 & 2 & 0 \\
\hline 19 & & & & & & & & & & & & & 237 & 1 & 1 \\
\hline $\begin{array}{l}\text { Total No. of } \\
\text { chromosomes }\end{array}$ & & 100 & 50 & & 100 & 50 & & 100 & 46 & & 100 & 42 & & 100 & 42 \\
\hline df & 10 & & & 9 & & & 11 & & & 9 & & & 18 & & \\
\hline$\chi^{2}$ value & 10. 2 & & & 7.80 & & & 36.9 & & & 19.4 & & & 23.9 & & \\
\hline $\mathrm{p}$ & 0.42 & & & 0.55 & & & 0.000 & & & 0.022 & & & 0.16 & & \\
\hline
\end{tabular}

Allele frequencies of the patients and of Japanese controls, and allele sizes are shown. Transmission disequilibrium was statistically evaluated by means of $\chi^{2}$ statistics for each marker. D14S43 and D14S71 showed significant differences.

of allele frequencies of the patients and those controls (Table 3). D14S43 and D14S71 out of five marker loci revealed significant differences $(p=0.0001, p=0.02$, respectively). To evaluate allelic association, the frequencies of the linked alleles 
from each family and those of controls were evaluated (Table 4). Statistical evidence of association was found between early-onset FAD and D14S43 polymorphism $(p<0.05)$. These results suggest that the early-onset FAD locus is located close to D14S43.

\section{Relationships between haplotype and age at onset}

Three alleles at D14S43 were determined by haplotype analysis. Then, we classified early-onset FAD families into three groups according to D14S43 alleles;

Table 4. Linkage disequilibrium on $14 \mathrm{q} 24.3$ in Japanese early-onset FAD families.

\begin{tabular}{|c|c|c|c|c|c|}
\hline Family \Marker & D14S53 & D14S76 & D14S43 & D14S71 & $\mathrm{D} 14 \mathrm{~S} 77$ \\
\hline TK-1 & $144 / 151^{*}$ & $179 / 167^{*}$ & 187 & 201 & 217 \\
\hline TK-2 & $151 / 151$ & $179 / 179$ & $161 / 187$ & $195 / 201$ & $207 / 215$ \\
\hline OS-2 & 151 & 171 & 187 & 207 & 215 \\
\hline OS-3 & 151 & 171 & 161 & 205 & 233 \\
\hline ME & 155 & 179 & 187 & 195 & 217 \\
\hline OI-2 & 151 & 179 & 187 & 207 & $215 / 223$ \\
\hline $\mathrm{AM}$ & 155 & 171 & 187 & 207 & 207 \\
\hline KF & 151 & $179 / 179$ & 167 & $205 / 207$ & 215 \\
\hline $\mathrm{KT}$ & $151 / 157$ & $179 / 179$ & $167 / 189$ & $203 / 207$ & $205 / 215$ \\
\hline $\mathrm{AC}-2$ & $151 / 151$ & $167 / 179$ & $187 / 191$ & $205 / 207$ & $213 / 215$ \\
\hline $\mathrm{HG}-5$ & $151 / 151$ & $167 / 179$ & $183 / 187$ & $193 / 207$ & $213 / 219$ \\
\hline \multirow[t]{8}{*}{ No. of alleles in FAD } & $144-1$ & $167-3$ & $161-2$ & $193-1$ & $205-1$ \\
\hline & $151-12$ & $171-3$ & $167-2$ & $195-2$ & $207-2$ \\
\hline & $155-2$ & $179-11$ & $183-1$ & $201-2$ & $213-2$ \\
\hline & $157-1$ & & $187-8$ & $203-1$ & $215-6$ \\
\hline & & & $189-1$ & $205-3$ & $217-2$ \\
\hline & & & $191-1$ & $207-7$ & $219-1$ \\
\hline & & & & & $223-1$ \\
\hline & & & & & $233-1$ \\
\hline Total No. of alleles & 16 & 17 & 15 & 16 & 16 \\
\hline $\begin{array}{l}\text { Frequency of } \\
\text { representative allele in } \\
\text { FAD (Control) }\end{array}$ & $\begin{array}{c}151-0.75 \\
(151-0.60)\end{array}$ & $\begin{array}{c}179-0.65 \\
(179-0.47)\end{array}$ & $\begin{array}{c}187-0.53 \\
(187-0.28)\end{array}$ & $\begin{array}{c}207-0.44 \\
(207-0.37)\end{array}$ & $\begin{array}{r}215-0.38 \\
(215-0.37)\end{array}$ \\
\hline$\chi^{2}$ & 1.3 & 1.8 & 3.9 & 0.27 & 0.0015 \\
\hline$p$ value & 0.25 & 0.18 & 0.049 & 0.61 & 0.97 \\
\hline
\end{tabular}

The alleles linked to the onset in each family are shown as the allele size. When recombinations were found (indicated as asterisks), both alleles were counted as being linked to the onset. Frequencies of representative allele in early-onset FAD chromosome are also summarized. A significant association $(\mathrm{p}<0.05)$ was found between the onset and D14S43. 
Table 5. Relation between haplotype of D14S43 and mean age at onset of early-onset FAD.

\begin{tabular}{lllll}
\hline $\begin{array}{l}\text { Group } \\
\text { (D14S43) }\end{array}$ & (D14S71) & Family & $\begin{array}{c}\text { Mean } \pm \text { SD (range) } \\
\text { age at onset } \\
\text { (years old) }\end{array}$ & $\begin{array}{c}\text { Overall mean } \pm \text { SD age } \\
\text { at onset } \\
\text { (years old) }\end{array}$ \\
\hline A (187) & 195 & ME & $34.8 \pm 2.05(33-38)$ & $42.8 \pm 6.74$ \\
& 201 & TK-1 & $47.5 \pm 3.29(45-56)$ & \\
& & TK-2 & $47.7 \pm 4.04(43-50)$ & \\
& 207 & OS-2 & $45.0 \pm 4.24(42-48)$ & \\
& & OI-2 & $40.5 \pm 2.12(39-42)$ & \\
& & AM & $41.7 \pm 3.64(36-46)$ & \\
B(161) & & AC-2 & $33.0 \pm 0.00(33-33)$ & \\
C (167) & 205 & HG-5 & $41.0 \pm 19.8(27-55)$ & \\
& 207 & OS-3 & $52.5 \pm 5.07(49-60)$ & $52.5 \pm 5.07$ \\
& & KT & $64.0 \pm 0 \quad(64-64)$ & $40.0 \pm 13.5$ \\
\hline
\end{tabular}

The haplotype linked to the onset in each family, the mean age and range at the onset are shown. Significant differences of the mean age at the onset were found between group $A$ and $B$, and between group $B$ and $C(p<0.05)$.

Group A was classified as families in which the onset of AD was linked with the $187 \mathrm{bp}$ allele, and consisted of ME, TK-1, TK-2, OS-2, OI-2, AM, AC-2, and HG-5; Group B was families with the 167 bp allele, and consisted of OS-3; Group C was families with the $161 \mathrm{bp}$ allele, and consisted of KT and KF. In TK-2, it was not determined by haplotype analysis whether the $161 \mathrm{bp}$ allele or the $187 \mathrm{bp}$ allele was linked with the disease. But TK-2 had the same geographic origin as TK-1 and the $187 \mathrm{bp}$ allele was shared between the families. Therefore, TK-2 was included in group $\mathrm{A}$. The mean $\pm \mathrm{SD}$ age at onset in group $\mathrm{A}, \mathrm{B}$, and $\mathrm{C}$ was $42.8 \pm$ $6.74,52.5 \pm 5.07$, and $40.0 \pm 13.5$ years, respectively (Table 5). According to ANOVA, the age at onset was significantly different among the groups $(p<0.05)$, and the significant differences of the mean age at onset were detected between group $A$ and $B$, and between group B and $C(p<0.05)$. This result suggests the existence of allelic heterogeneity in early-onset FAD.

\section{DISCUSSION}

Our results indicate that the major locus for early-onset FAD is localized on $14 q 24.3$, and is closely linked to D14S43. The order of markers on $14 q 24.3$ has been determined by linkage and physical mapping as telomere-D14S53-D14S76D14S43-D14S71-D14S77-centromere. In our study, linkage analysis revealed significant lod scores for only D14S77, and no recombination events were found for D14S77 and D14S43. The recombinations found in TK-1 and KF were dem- 
onstrated using DNAs extracted from paraffin blocks. Contamination with other tissues might be possible during the process of paraffin embedding. Therefore, these recombinations seem not to be reliable. The highest lod scores of early-onset FAD were reported for D14S43 and D14S53 (Schellenberg et al, 1992; St GeorgeHyslop et al., 1992: Van Broeckhoven et al., 1992; Mullan et al., 1992b). The interval between these markers is estimated to be $2.1 \mathrm{cM}$ (Weissenbach et al, 1992). The reason why D14S77 showed the highest lod score in this study can be explained by its having a larger number of alleles than D14S53 and D14S43.

Comparison of allele frequencies between all early-onset FAD patients and controls indicated transmission disequilibrium between the early-onset FAD locus and D14S43 as well as D14S71, supporting the positive linkage. This phenomenon could be strongly influenced by the geographic origins of patients. Then, we selected the alleles linked with the onset of AD in each family, and an association due to linkage disequilibrium was detected only at D14S43. These results suggest that the major early-onset FAD locus is located close to D14S43. The families used in this study were distributed in Western Japan, and the most frequent alleles in the patients were the same as those of controls for all markers. But the 167 bp allele of D14S43 was not found in controls. Moreover, when early-onset FAD patients were divided into three groups by D14S43 allele, the age at onset among the groups was significantly different. These results suggest the existence of allelic heterogeneity for early-onset FAD. OS-3 was the only family linked with the 161 bp allele of Di4S43. Suppression of the calcium response at S phase in cell cycle was reported in the fibroblasts of the patient with APP717:Val $\rightarrow$ Ile mutation and of the patient in OS-2, but not of the patient in OS-3 (Tatebayashi et al., 1995), This observation supported the existence of allelic heterogeneity. This possibility will remain unconfirmed until a causative gene is isolated.

Linkage disequilibrim is based on a founder effect, but the ability to detect this phenomenon is strongly affected by the allele frequency of polymorphic marker analyzed. We used 50 controls distributed in the vicinity of Osaka and Hyogo prefectures, both of which are located in Western Japan. The allele frequency of D14S43 in the Japanese population has been reported (Takiyama et al., 1993), but their result was different from that of our study, suggesting that population variation exists between Western and Eastern Japan. Our controls were composed of individuals without dementia; therefore, the characteristics of the control subjects could be another cause of the difference. Allele sizes at D14S43 in our study were 4 bp longer than those reported previously (Schellenberg et al., 1992). But even when adjusting the allele sizes, allele frequency in the Japanese population was still significantly different from that reported in Caucasians (Wang and Weber, 1992). This difference might be due to difficulty in determining the allele size at D14S43.

Linkage disequilibrium has recently been applied to obtain fine mapping of disease genes. Recent studies indicated that linkage disequilibrium can be detected typically in regions of $1-2 \mathrm{cM}$ in size or smaller ( $\mathrm{Yu}$ et al., 1994). AD is a hetero- 
geneous disorder, and linkage study of early-onset FAD indicated non-allelic heterogeneity (Van Duijn et al., 1994). But it should be noted that allelic association can be detected in the case that a major allele linked with the disease exists. Our results indicated that one of the closest markers is D14S43, which is located within the $3.0 \mathrm{cM}$ region between D14S71 and D14S76 (Weissenbach et al., 1992). It has been reported that the activity of $\alpha$-ketoglutarate dehydrogenase in the brain and fibroblasts was reduced in AD patients (Gibson et al., 1988; Sheu et al., 1994). The $\alpha$-ketoglutarate dehydrogenase complex is composed of three protein subunits, one of which is dihydrolipoamide succinyltransferase (DLST). The gene of DLST is localized to 14q24.3 (Ali et al., 1993), and its sequence and D14S43 were found in the same clone of a yeast artificial chromosome library (unpublished data), suggesting that this gene is a candidate gene of early-onset FAD.

Acknowledgments We greatly thank Dr. Hisao Ikeda, Dept. of Psychiatry, Kochi Medical School, and Dr. Toshio Ikeda, Dept. of Psychiatry, Fujita Health University School of Medicine for performing clinical examinations and providing blood samples. This work was supported by a Grant-in-Aid for Scientific Research on Priority Areas, No. 04268102, from the Ministry of Education, Science and Culture of Japan.

\section{REFERENCES}

Ali G, Cai X, Sheu K-FR, Szato P, Cooper AJL, Blass JP (1993): $\alpha$-Ketoglutarate dehydrogenase: a candidate gene for Alzheimer's disease? J Neurochem 61 (Supple): S177 (Abstract)

Chartier-Harlin M-C, Crawford F, Houlden H, Warren A, Hughes D, Fidani L, Coate A, Rossor M, Roques P, Hardy J, Mullan M (1991): Early-onset Alzheimer's disease caused by mutations at codon 717 of the $\beta$-amyloid precursor protein gene. Nature 353: 844-846

Fujigasaki H, Naruse S, Kaneko K, Hirasawa H, Tsuji S, Miyatake T (1994): Mutational analysis of the amyloid precursor protein gene in Japanese familial Alzheimer's disease kindreds. Hum Genet 93: 460-462

Gibson GE, Sheu K-FR, Blass JP, Baker A, Carlson KC, Harding B, Perrino P (1988): Reduced activities of thiamine-dependent enzymes in the brains and peripheral tissues of patients with Alzheimer's disease. Arch Neurol 45: 836-840

Goate A, Chartier-Harlin M-C, Mullan M, Brown J, Crawford F, Fidani L, Giuffra L, Haynes A, Irving N, James L, Mant R, Newton P, Rooke K, Roques P, Talbot C, Pericak-Vance M, Roses A, Williamson R, Rossor M, Owen M, Hardy J (1991): Segregation of a missense mutation in the amyloid precursor protein gene with familial Alzheimer's disease. Nature 349: 704706

Haestbacka J, Chapelle A, Mahtani MM, Clines G, Reeve-Daly MP, Daly M, Hamilton BA, Kusumi K, Trivedi B, Weaver A, Coloma A, Lovett M, Buckler A, Kaitila I, Lander E (1994): The diastrophic dysplasia gene encodes a novel sulfate transporter: positional cloning by finestructure linkage disequilibrium mapping. Cell 78: 1073-1087

Harley HG, Brook JD, Floyd J, Rundle SA, Crow S, Walsh KV, Thibault M-C, Harper PS, Shaw DJ (1991): Detection of linkage disequilibrium between the myotonic dystrophy locus and a new polymorphic DNA marker. Am J Hum Genet 49: 68-75

Kamino K, Orr HT, Payami H, Wijsman EM, Alonso ME, Pulst SM, Anderson L, O'dahl S, Nemens E, White JA, Sadovick AD, Ball MJ, Kaye J, Warren A, McInnis M, Antonarakis SE, Korenberg JR, Sharma V, Kukull W, Larson E, Heston LL, Martin GM, Bird TD, Schellen- 
berg GD (1992): Linkage and mutational analysis of familial Alzheimer's disease kindreds for the APP gene region. Am J Hum Genet 51: 998-1014

Lannfelt L, Lilius L, Appelgren H, Axelman K, Forsell C, Liu L, Johansson K, Graff C (1993): No linkage to chromosome 14 in Swedish Alzheimer's disease families. Nature Genet 2: 218-219

McKhann G, Drachman D, Folstein M, Katzman R, Price D, Stadlan EM (1984): Clinical diagnosis of Alzhermer's disease: report of the NINCDS-ADRDA Work Group under the auspices of Department of Health and Human services Task Force on Alzheimer's Disease. Neurology 34: 939-944

Mullan M, Crawford F, Axelman K, Houlden H, Lilius L, Winblad B, Lannfelt L (1992a): A pathogenic mutation for probable Alzheimer's disease in the APP gene at the N-terminus of $\beta$-amyloid. Nature Genet 1 : 345-347

Mullan M, Houlden H, Windelspecht M, Fidani L, Lombardi C, Diaz P, Rossor M, Crook R, Hardy J, Duff K, Crawford F (1992b): A locus for familial early-onset Alzheimer's disease on the long arm of chromosome 14 , proximal to the al-antichymotrypsin gene. Nature Genet 2: $340-342$

Murrell J, Farlow M, Ghetti B, Benson MD (1991): A mutation in the amyloid precursor protein associated with hereditary Alzheimer's disease. Science 254: 97-99

Nagano K, Katsuya T, Kamino K, Yoshiiwa A, Ikeda M, Tanabe H, Takeda M, Nishimura T, Yoshizawa T, Tanaka H, Tsuji S, Yanagisawa K, Naruse S, Miyatake T, Sakaki Y, Nakajima T, Yoneda H, Sakai T, Imagawa M, Uragami, K, Ii K, Matsumura H, Miyoshi I, Miki T, Ogihara T (1995): Familial Alzheimer's disease in Japanese population. Jpn J Geriat 32: 11 1-122

Naruse S, Igarashi S, Kobayashi H, Aoki K, Inuzuka T, Kaneko K, Shimizu T, Iihara K, Kojima T, Miyatake T, Tsuji S (1991): Mis-sense mutation Val- $\rightarrow$ Ile in exon 17 of amyloid precursor protein gene in Japanese familial Alzheimer's disease. Lancet 337: 978-979

Ott $J$ (1991): Age-dependent penetrance. In: Ott $J$ (ed). Analysis of Human Genetic Linkage, 2nd ed., Johns Hopkins University Press, Baltimore and London, pp 155-161

Pericak-Vance MA, Conneally PM, Merritt AD, Roos RP, Vance JM, Yu PL, Norton JA Jr, Antel JP (1979): Genetic linkage in Huntington's disease. In: Chase TN, Wexler NS, Barbeau A (eds). Advances in Neurology, Vol 23, Raven Press, New York, pp 59-72

Schellenberg GD, Pericak-Vance MA, Wijsman EM, Moore DK, Gaskel PC Jr, Yamaoka LA, Bebout JL, Anderson L, Welsh KA, Clark CM, Martin GM, Roses AD, Bird TD (1991): Linkage analysis of familial Alzheimer disease, using chromosome 21 markers. Am $\mathrm{J}$ Hum Genet 48: $563-583$

Schellenberg GD, Bird TD, Wijsman EM, Orr HT, Anderson L, Nemens E, White JA, Bonnycastle L, Weber JL, Alonso ME, Potter H, Heston LL, Martin GM (1992): Genetic linkage evidence for a familial Alzheimer's disease locus on chromosome 14. Science 258: 668-671

Sharma V, Smith L, Allen L, Magenis RE, Litt M (1991): Dinucleotide repeat polymorphism at the D14S43 locus. Nucleic Acids Res 19: 1722

Sheu KFR, Cooper AJL, Koike K, Koike M, Lindsay JG, Blass JP (1994): Abnormality of the $\alpha$ ketoglutarate dehydrogenase complex in fibroblasts from familial Alzheimer's disease. Ann Neurol 35: $312-318$

St George-Hyslop P, Haines J, Rogaev E, Mortilla M, Vaula G, Pericak-Vance M, Foncin J-F, Montesi M, Bruni A, Sorbi S, Rainero I, Pinessi L, Pollen D, Polinsky R, Nee L, Kennedy J, Macciardi F, Rogaeva E, Liang Y, Alexandrova N, Lukiw W, Schlumpf K, Tanzi R, Tsuda T, Farrer L, Cantu J-M, Duara R, Amaducci L, Bergamini L, Gusela J, Roses A, Crapper McLachlan D (1992): Genetic evidence for a novel familial Alzheimer's disease locus on chromosome 14. Nature Genet 2: 330-334

Takiyama Y, Nishizawa M, Tanaka H, Kawashima S, Sakamoto H, Karube Y, Shimazaki H, Soutome M, Endo K, Ohta S, Kagawa Y, Kanazawa I, Mizuno Y, Yoshida M, Yuasa T, Horikawa $Y$, Oyanagi K, Nagai H, Kondo T, Inuzuka T, Onodera O, Tsuji S (1993): The gene for 
Machado-Joseph disease maps to human chromosome 14q. Nature Genet 2: 300-303

Tanzi RE, Vaula G, Romano DM, Mortilla M, Huang TL, Tupler RG, Wasco W, Hyman BT, Haines JL, Jenkins BJ, Kalaitsidaki M, Warren AC, McInnis MC, Antonarakis SE, Karlinsky H, Percy ME, Connor L, Growdon J, Crapper-McLachlan DR, Gusela JF, St George-Hyslop PH (1992): Assessment of amyloid $\beta$-protein precursor gene mutations in a large set of familial and sporadic Alzheimer disease cases. Am J Hum Genet 51: 273-282

Tatebayashi T, Takeda M, Kashiwagi Y, Okochi M, Kurumadani T, Sekiyama A, Kanayama G, Hariguchi S, Nishimura T (1995): Cell-cycle-dependent abnormal calcium response in fibroblasts from patients with familial Alzheimer's disease. Dementia 6: 9-16

Van Broeckhoven C, Backhovens H, Cruts M, De Winter G, Bruyland M, Cras P, Martin J-J (1992): Mapping of a gene predisposing to early-onset Alzheimer's disease to chromosome 14q24.3. Nature Genet 2: 335-339

Van Duijn CM, Hendriks L, Farrer LA, Backhovens H, Cruts M, Wehnert A, Hofman A, Van Broeckhoven C (1994): A population-based study of familial Alzheimer disease: linkage to chromosomes 14, 19, and 21. Am J Hum Genet 55: 714-727

Wang Z, Weber JL (1992): Continuous linkage map of human chromosome 14 short tandem repeat polymorphisms. Genomics 13: 532-536

Warren AC, McInnis MG, Kalaitsudaki M, Cox TK, Blaschak J, Chakravarti A, Antonarakis SE (1993): D21S210: a highly polymorphic (GT) $n$ marker closely linked to the $\beta$-amyloid protein precursor (APP) gene. Hum Genet 91: 87-88

Weir BS, Cockerham CC (1978): Testing hypothesis about linkage disequilibrium with multiple alleles. Genetics 88: 633-642

Weissenbach J, Gyapay G, Dib C, Vignal A, Morissette J, Millasseasu P, Vaysseix G, Lathlop M (1992): A second-generation linkage map of the human genome. Nature 359: 794-801

Yoshioka K, Miki T, Katsuya T, Ogihara T, Sakaki Y (1991): The ${ }^{717} \mathrm{Val} \rightarrow$ le substitution in amyloid precursor protein is associated with familial Alzheimer's disease regardless of ethnic groups. Biochem Biophys Res Commun 178: 1141-1145

Yoshizawa T, Komatsuzaki Y, Iwamoto H, Mizusawa H, Kanazawa I (1993): Screening of the mis-sense mutation producing the ${ }^{717} \mathrm{Val} \rightarrow$ Ile substitution in the amyloid precursor protein in Japanese familial and sporadic Alzheimer's disease. J Neurol Sci 117: 12-15

Yu C, Oshima J, Goddard KAB, Miki T, Nakura J, Ogihara T, Poot M, Hoehn H, Fraccaro M, Puissan C, Martin GM, Schellenberg GD, Wijsman EM (1994): Linkage disequilibrium and haplotype studies of chromosome 8p11.1-21.1 markers and Werner syndrome. Am J Hum Genet 55: 456-364 